\title{
THE WAREHOUSING AS AN ELEMENT OF ARMY LOGISTICS SYSTEM IN CONDITIONS OF ARCTICS (FROM EXPERIENCE OF BULGARIAN- RUSSIAN COOPERATION)
}

\author{
Venelin Terziev ${ }^{1}$, Oleg Latyshev ${ }^{2}$, Marin Georgiev ${ }^{3}$ \\ ${ }^{1}$ Corresponding Member of the Russian Academy of Natural History, Moscow, Russia, Prof. D.Sc. \\ (Ec.), D.Sc. (National Security), D.Sc. (Social Activities), Ph.D., National Military University, Veliko \\ Tarnovo, Bulgaria; University of Rousse, Rousse, Bulgaria, terziev@skmat.com \\ ${ }^{2}$ Academician of the Russian Academy of Natural History, Moscow, Russia, Professor, Ph.D., \\ D.Sc., papa888@list.ru \\ ${ }^{3}$ Ph.D, National Military University, Veliko Tarnovo, Bulgaria, clementon@abv.bg
}

\begin{abstract}
Storing material resources is a back-up function of military logistics, but its proper organization and successful improvement is a guarantee for effective and efficient realization of the whole logistics support process. Currently, many warehouses at the various command levels are not necessary due to decrease in stock volume. This leads to significant staff reduction as a result of the elimination of military units and staff changes in warehouse structures, but at the same time staff duties are not reduced. The objective reality at the moment shows that warehousing activities are carried out through tolerating many and considerable omissions or compromises. For this reason it is advisable to elaborate the whole warehousing process in the Bulgarian Army (BA). The aim of this study is to analyze the state of logistics and warehousing in the Bulgarian Army.
\end{abstract}

Keywords: logistics, logistics system of Bulgarian army, warehousing.

\section{INTRODUCTION}

The dislocation of the Bulgarian Army takes place much more southerly than the arctic latitudes. Therefore, the material of this work was prepared in cooperation with Russian scientists. Conditions of permafrost in the Arctic zone make the process of storing provisions, uniforms and weapons more expensive and require special equipment. On the one hand, all the components of the army logistics should always be equally accessible and in good working order, despite the particularly low air temperature, and the zone of low atmospheric pressure characteristic of the Arctic. On the other hand, one should take into account the fact that the use of more expensive warehouse equipment requires additional substantial allocations that may lead to unpopular measures of political practice in the country's population in the form of new taxes. In turn, the new missions and tasks, BA living environment and the military-political reality in the world necessitated the inauguration of a transformation process of the organizational structure, functional relationships and 
administrative practice in the Ministry of Defense, Defense Headquarters of the Bulgarian Army. The aim of this transformation is to build up modern, usable and effective armed forces.

A new approach is necessary as to realize the principles of compatibility, usability, modularity, functionality and expeditiousness. The main efforts should be directed towards reaching multi-functionality in order to increase the operational effect and to reduce expenditures for staff, infrastructure, fighting equipment and battle training.

We understand that it is possible to achieve the desired balance between the need for new warehouse equipment for its use in fundamentally new climatic, geographic and geophysical conditions, and the need to use material means for this purpose extremely rationally.

One priority of armed forces development is progressive building up of the necessary operational capacity within an integrated system for defense planning.

The development of effective capacity requires permanent transformation, based on the lessons from participation in operations and missions, flexibility in conception development, effective military and logistics support, capacity for deployment and independent task fulfillment for a long period of time.

The presence of various arms of the Russian army in the Arctic zone helps to solve a whole range of tasks that are closely related. It:

Protection of the northern border of the Russian Federation, which is the largest in terms of world scale in the Arctic zone;

Escorting cargo ships navigating in the Arctic zone along the northern sea route;

Security escort of mobile drilling rigs, which lead to the extraction of minerals in the water area of the Arctic;

Protection of industrial enterprises of the Russian Federation in the Arctic zone, etc.

Storing material resources is a back-up function of the military logistics, but its proper organization and successful improvement is a guarantee for effective and efficient realization of the whole logistics support process.

The rapid warming of the climate in the Arctic zone, on the one hand, can somewhat reduce the level of requirements for the preservation of the logistics of the army units, and on the other hand - prompts to increase the costs allocated to the maintenance of housing infrastructure for the army and its maintenance staff.

Storing material resources for the Bulgarian Army is considered at two levels:

First level - organizational and management structure of BA warehousing

Second level - state of BA warehouses and organization of warehousing activities there.

Such a subdivision into the levels is typical for the Russian army, taking into account the variety of climate characteristics and the specifics of deploying the armed forces in various regions of Russia.

For the purpose of this study the second level is analyzed.

The aim of this study is to analyze the role of warehousing as an element of Bulgarian army logistics system and the states of warehouses of Bulgarian army.

This research will analyze the state of the Central Supply Base /CSB/, Regional Supply Bases /RSB/ and other BA warehouses and warehousing activities carried out there.

\section{ROLE OF WAREHOUSING AS AN ELEMENT OF BA LOGISTICS SYSTEM}

The reduced staff numbers of the Bulgarian Army and limited financial resources for defense and security makes it necessary to improve the factors for its effectiveness, incl. the logistic system.

In turn, for the Russian army in recent years is characterized by a reduction in the service life to one year, as well as a principal increase in the percentage of service under the contract.

Building and maintaining contemporary warehouses requires a complex approach to their design and detailed preliminary plans to determine the need of warehouse area and volume, the necessary warehouse equipment and technics and their placement inside the warehouse.

The construction of storage facilities of the Russian army in the Arctic zone in the previous decades could be conducted directly on permafrost. Now, as we understand it, the design of army warehouses for Arctic 
conditions must undergo fundamental changes, since otherwise the intensive thawing of permafrost will inevitably entail human sacrifices, unjustified expenditure of material and technical resources, and irreparable changes in architectural structures.

Currently, many warehouses at the various command levels are not necessary due to decrease in stock volume. This leads to significant staff reduction as a result of the elimination of military units and staff changes in warehouse structures, but at the same time staff duties are not reduced. The objective reality at the moment shows that warehousing activities are carried out through tolerating many and considerable omissions or compromises.

For this reason it is advisable to improve the whole warehousing process in the Bulgarian Army.

The warehouses of the Russian Army in the Arctic desert are built thanks to the delivery of all necessary materials along the Northern Sea Route. The first food stores and fuel storage facilities in permafrost conditions are designed to serve the needs of the personnel of the North Clover military base, which is located on the island of Kotelnyj, the archipelago of the Novosibirsk Islands.

The next fundamentally new step in developing innovative technologies for storing the material and technical resources of the Russian army was the construction of a second military base. It is called the "Arctic Shamrock" and is located on the island of Alexandra Land in the Franz Josef Land archipelago. The stores of food and fuel have a capacity corresponding to the requirements of a garrison of 150 people for 18 months. Since cargo vessels can use the Northern Sea Route only four full months a year, the garrison supply is designed for autonomous residence in a five-story housing and administrative complex and performance of service tasks. In addition to storage facilities, the infrastructure of the base includes a power station, as well as a water treatment plant designed for 700 tons of water. Water is obtained by disinfection of snow. In addition, as part of the military base "Northern Shamrock" operates a shore pumping station for fuel replenishment, sewage facilities and heated garages for military equipment.

The Ministry of Defense manages and coordinates the activity of logistics support of the armed forces. In cooperation with the other ministries and administrations, it develops and presents for confirmation to the higher defense management authorities plans for due provisioning and use of military and civil resources in operations at time of crisis, conflicts and war. Special attention is given to national resources, development of transport, infrastructure and industry as well as the activities related to force deployment and support by the hosting country.

An integrated system for logistics support management is built up that consists of organizational structure (staff, equipment and installations), doctrines, procedures and communication and information technologies. This system provides due and expedient information for planning, management and control of the activities within all structures and levels.

The use of information and communication technologies in solving the tasks of the army units of the Arctic zone provides for the use of hardware and software that are capable of withstanding permafrost conditions for a considerable time in order to create a satisfactory quality of work for each specialist in the army. To do this, all necessary spare parts of the hardware stock of information means should be in warehouses in sufficient quantity and the most modern modifications. As part of the army units should be specially trained members of the team, who must be able to quickly and skillfully make a replacement and adjustment of equipment, which for one reason or another has failed.

Logistics support management includes: continuous gathering, summarizing, examining and analyzing data about the situation; making a decision for logistics support organization; planning of logistics support; giving tasks to subordinates; organizing and maintaining interaction; organizing and carrying out activities for increasing the readiness and durability of logistics support forces, their protection, security and defense; organizing the system for management, leadership and control.

Given the short-term nature of summer navigation on the Northern Sea Route, it must be remembered that the garrisons of the Arctic zone can receive at their disposal rapidly obsolete equipment. This has a direct bearing on the quality of the work of storage facilities - sensors for monitoring temperature and humidity, air contamination of the arctic military depot, reaching the maximum permissible level of concentration in case of storage of harmful substances for breathing. Therefore, it is necessary to complete the cargoes arriving at the disposal of the Arctic regions, with the equipment of the newest models that have not yet entered mass production. However, before sending them to the northern military bases, they must undergo a multifactor test of operability in conditions, as close as possible to the temperature and atmospheric pressure characteristic of the Arctic zone.

The main body for logistics support management at strategical level is Directorate "Logistics" at the Defense 
Headquarters.

BA logistics support management at operational level is fulfilled by "Logistics" departments, by the Joint Forces Command of the separate armed forces (Armed Forces, Air Forces and Maritime Forces), and at tactical level by "Logistics" Departments at the bases and brigades and by "Logistics" sections at the battalions.

"Logistics" Brigade is a tactical military unit but fulfills functions at operational level regarding storing operational stocks of armaments, technics and material resources for the BA, as well repairing the technics of the JFC subordinate military units. It is deployed throughout the whole national territory and it provides material resources of all classes for all types of armed forces (AF) in peacetime. Completed with servicemen and civil servants at $94 \%$, it is able to fulfill the assigned tasks regarding logistics support of the Bulgarian Army units in the country and contingents of foreign missions.

The new strategic environment and the economic potential of the Republic of Bulgaria require continuous improvement of the structures for Brigade Logistics support at all levels and optimization of their activity.

"Logistics" Brigade has 28 subordinate military units, dislocated throughout the whole country.

The military unit in the village of Negushevo, region Sofia is a center for logistics support and is also called Central Supply Base - CSB, which is established on the grounds of Ministerail Order No OX0020/17.08.2000, since 01.09.2000.

In organizational aspect the CSB is directly subordinate to "Logistics" Brigade and the performed tasks are related to the requirements of the Doctrine for Bulgarian Army Logistics and Conception for United Material and Technical Supply.

For fulfillment of logistic operations CSB - Negushevo has at its disposal a logistic-provisioning company with three squads - transport, repair and housekeeping.

It should be emphasized that the SCB takes a particularly important place within the general scheme of BA logistics support. It is a supply body of "Logistics" Brigade and its main task is to provide BA subdivisions with all types of material resources. The CSB is an independent military unit with a specific organizational and staff structure that allows successful completion of tasks assigned to the military forces, namely total, due and quality provisioning of BA units.

There are two Regional bases for supplying with logistic property directly subordinate to the Central Supply Base which are called Regional Supply Bases (RSB) situated in the city of Plovdiv and the village of Radko Dimitrievo - Shumen region, namely:

In the city of Plovdiv - First Regional Base for storing logistic property and control on foods, installations and vehicles of high danger.

In the village of Radko Dimitrievo, Shumen region - Second Regional Base for storing logistic property and control on foods, installations and vehicles of high danger.

The main tasks fulfilled by RSBs are: summarizing the needs declared by the supplied military units; coordinating the declared quantities with "Logistics" Brigade; preparing payment documents for the delivery companies; organizing and controlling the storage of war-time stocks of material resources in the national economy; control on the execution of contracts and contract discipline, in conformity with contract articles; control over high pressure machines, lightening-conduct, fire safety, and last but not least the quality of food products delivered to RSB and the end user-units.

\section{ANALYSIS OF THE CENTRAL SUPPLY BASE, REGIONAL SUPPLY BASES AND OTHER WAREHOUSES OF THE BULGARIAN ARMY}

For analyzing the current state of warehousing in the Bulgarian Army a survey was conducted among the officers, sergeants and civil staff employed in the CSB - village of Negushevo and in the RSBs - village of Radko Dimitrievo and city of Plovdiv, as well the warehouses for storing motor vehicles - village of Resen and for armament - village of Dalga laka. The survey was held in the period 2012-2016. The specific method for warehousing examination is based on Bolton's system for evaluation and quality of warehousing services.

Survey questions are grouped into 9 sections. Sections include the following main topics of research: state of the warehouse buildings and fields, equipment safety and security, sanitary conditions and buildings maintenance, servicing RSBs and the units situated in the responsibility zone, warehouse staff, warehouse operations on acceptance and dispatch of material resources, losses/damages of material resources, accountability and annual inventory. 
One of the necessary elements of the functioning of storage facilities - both in the Bulgarian and Russian armies - is their safety for service personnel. The quality of ventilation of storage facilities is one of the key indicators of their sanitary and technical support. Sufficient illumination of the warehouse of the military base of Russian Army acts as the main source of its functioning, taking into account the peculiarities of the Arctic zone, where natural light for a long time cannot be the main source of illumination.

Based on the survey results the state of BA warehousing could be outlined in the following main directions:

State analysis of buildings and fields

Despite being built many years ago, buildings and fields in the monitored sites are in good condition. In Negushevo and Radko Dimitrievo warehouse buildings need renovation of exterior and repair of roof constructions. However, major repair costs would be necessary which cannot be currently afforded and chief officers are forced to undertake temporary solutions for mitigating the problems.

Parking lots and roads are in good condition excluding RSB - Plovdiv, where roads are narrow and it is difficult to manoeuvre.

Although in the CSB, RSB - Radko Dimitrievo and Resen bases there are conditions for using railway transport, it is not used. According to the contracts with delivery companies material resources are delivered vie motor transport to CSB or RSB. At present, railway transport is used as a transportation method only in the warehouse base Dalga Laka.

There are many ways for improving the supply of warehouse bases through various cargo vehicles. Head officers state that it is better economically grounded to use small cargo vehicles - mini-busses with bigger range, lower loading capacity and lower operating costs as well.

Another problem is the lightening condition. Good lightening is a precondition for safe fulfillment of warehousing activities and for protecting material resources, as CSB and RSBs keep high value stocks. Problems come mainly from the old electric network and the lack of electrical luminaires for due change.

Analysis of equipment safety and security

The main problems found in the analysis of equipment safety and security are related to the lack of modern tools for monitoring and fire extinguishing /sprinkle system and smoke detectors/. Indeed, the existing fire equipment and tools are ready-to-use. In warehouse bases there are fire equipment and tools next to every storage building - able to carry and transport fire-extinguishers, trench instrument, pumps, etc. Fireextinguishers are accessible and correctly situated to be easily found in case of need. They are kept in good working condition and are periodically checked-up at an authorized service-station where the relevant certificate is issued.

Fire safety in warehouse bases is subject to periodical unexpected inspections by the Military Police and "Logistics" Brigade special bodies. The assessments of the latest inspections in the monitored warehouse bases are "Excellent".

The level of fire safety is maintained also with frequent instructions of the warehouses staff, the presence of fire safety instructions in every warehouse and office, and putting well-visible "No smoking" signs.

As a positive aspect of the examined sphere could be outlined the high discipline of warehouse staff regarding buildings safety. In order to improve safety, it should be invested in modern fire protection systems - smoke detectors, sprinkle systems and modern communication systems for early warning of fire forces.

Warehouse staff analyses

The survey shows that warehouse staff is controlled and supported by the management in doing warehousing activities. A committee of qualified persons is established when safekeeping objects - clothes, shoes, etc. are accepted in RSB and CSB, who verify supply quantity and quality on the spot.

The limited number of warehouse staff provides for better management control. In the time when workers are not directly occupied with their main warehouse duties they fulfill other tasks as well, such as cleaning and maintenance of outside regions, construction and repair activities, etc.

There are regular trainings for the SCB and RSB warehouse staff according to the plan of supply bases directors. The main aims in this aspect are to introduce new types of resources, get acquainted with new regulatory acts regarding warehousing activity, studying the basic workplace health and safety rules. Practical lessons on safety rules implementation, rules for work with dangerous substances and work with the equipment and tools for loading and unloading services in the warehouse are organized in the beginning of every year. 
The conducted survey and the monitoring of warehousing activities organization in BA show that the main communication methods used for their fulfillment are personal contact /morning posting of sentries and personal meetings/ and use of stationary/mobile phone. In BA warehouses there are no modern communication tools - computer systems /data transferring systems, pick-by-light systems, vision display, etc./

\section{Analysis of warehousing activities - acceptance and dispatch of material resources}

Acceptance of material resources/goods/ in the examined warehouses is done with a view to check their quantity and quality and their compliance with the signed delivery contracts. For the acceptance of newly arrived material stocks from civil firms a committee is established which includes people acquainted with the specific features of different resources - representatives of the warehouse bases /including the head store/. When the quality of safekeeping objects is accepted, it is compared to the available specimen of the same goods.

It could be concluded that there are good relations with suppliers. Usually, material resources are dispatched with transport owned by the supplier and this helps to avoid controversies about protecting material resources during transportation. There are cases of refusal to accept the material which usually happen when the delivery arrives at non-working hours.

Dispatching material resources to the units and sections in the responsibility area is done on the basis of the information flow generated in the system of requests and orders. Usually, material resources are dispatched to the sections with own transport of the warehouse bases which does not totally correspond to delivery requirements. The problem comes from the existing old large-size machines which sometimes cannot be used at full capacity and creates too high operational costs. Transport planning in the monitored warehouses is optimized so that within one transport route several military shops and units - material recipients could be visited.

An important indicator for warehouse effectiveness is the available storage space level of use. In the examined warehouses the assessment of this indicator is good. The examined storage buildings are with different sizes and construction solutions but everywhere there is the ambition for maximum use of the efficient storage space. There are little reserves in the safe-keeping storage centers - Negushevo and Plovdiv because of storing waste materials in the active storage areas and not enough using of stands as a universal storage system.

The analysis of the examined warehousing activity elements requires purposeful work and efforts in the following directions:

Investments in buildings maintenance and lightening are necessary, as well as purchasing modern transport means corresponding to the contemporary features of material flow in the logistic system;

In warehouse bases for storing material property could be applied good practices used in the warehouses for storing motor vehicles and armament regarding maximum utilization of storage space and the broad use of stands as a universal system for storing material resources;

Despite the staff good professional skills, more attention should be paid to their safety and security and providing good working conditions. In the warehouses for storing material property it would be purposeful to develop procedures for the use of safety technics and equipment in doing warehousing activities.

In the conditions of contemporary tasks and challenges faced by the logistics support and in particular Bulgarian Army warehousing, the following conclusions could be drawn:

Historically, warehousing has been an important element of the Bulgarian Army logistic system and has developed dynamically during the years. There are two main challenges standing in front of warehousing creating stocks that could completely satisfy military needs of material resources and reaching higher effectiveness of the warehousing function.

Higher level of warehousing could be achieved only through constant monitoring of the warehousing activities state and searching for ways of improvement. It is important to involve in the current analysis the warehouses directors and staff as they are well acquainted with the strengths and weaknesses of the offered logistic service. The applied approach should be pointed at investing in fields of warehousing that are lagging far behind world practices and threaten the fulfillment of the main warehouse functions, such fields are: investments in building maintenance, investments in modern information and communication systems, investments in safety and improving working conditions in the warehouses.

One way to achieve maximum effect in logistics is to create and use modern information systems. Only 
generating and providing accurate information in real time would allow directors to take the most appropriate managerial decisions. Through using modern information systems for logistics management we would be able to use defense resources effectively and economically. The information system "BA Logistics" is an example for the ambition to reach this aim and its full implementation in all units of the Bulgarian Army will show the whole set of advantages that it provides (Banabakova, 2010, p. 12; Terziev, Banabakova, Ilsheva, Georgiev, 2017, pp. 28-43; Terziev, Banabakova, Ilsheva, Georgiev, 2017a, pp. 15-28; Terziev, Arabska, 2015, pp.908-917; Terziev, Arabska, 2015, pp.908-917; Terziev, Banabakova, Ilsheva, 2018, pp. 503-510; Terziev, Banabakova, Stefanov, 2017b, pp.1389-1402; Terziev, Banabakova, Ilsheva, 2017c, pp.133-137; Terziev, Banabakova, Stefanov, 2017d, pp.289-301; Terziev, Banabakova, Stefanov, 2017e, pp.475-484; Terziev, V., Banabakova, Stefanov, Georgiev, 2017f, pp. 213-218).

\section{CONCLUSION}

In conclusion, regarding the new tasks given to the Bulgarian army, the logistics support system, and warehousing in particular, should create and provide a broad set of logistic services in the country and also for foreign operations and mission's fulfillment. Foreign experience and the advantages of Russia and Bulgaria should be utilized. At the same time, it should be agreed that operations supply would largely depend on the specific conditions of environment and on this grounds should be found flexible approaches and solutions for every single case.

We are confident that the cooperation of the scientists of Russia and Bulgaria will contribute to the strengthening of peace, mutual understanding and comprehensive friendly relations between our powers. The results of the Russian-Bulgarian research projects will form the basis for the effective use of the Arctic zone on the principles of natural appropriateness and culturality. In turn, the provision of military bases of the Russian army in the Arctic zone is based on constantly developing technical innovations, opportunities for upgrading the skills and professional retraining of personnel of military units, as well as the use of information and communication technologies (Terziev, Banabakova, 2017g, s.148; Terziev, Arabska, 2015a, pp.49-60; Terziev, Banabakova, 2017h, 197 p).

\section{REFERENCE LIST}

Banabakova, V. (2010). Business Logistics. // Publishing house Faber, Veliko Tarnovo, 2010, p. 12.

Terziev, V., Banabakova, V., Ilsheva, M., Georgiev, M. (2017). Logistics services strategies. // Scientific journal «Economics and finance». GPG Publishing Group, Pretoria, South Africa, Challenges and opportunities of scientific thought development: Collection of scientific articles, 2017, pp. 28-43, ISBN 978-0-9942661-6-3.

Terziev, V., Banabakova, V., Ilsheva, M. Georgiev, M. (2017a). Logistic service levels // Scientific journal «Economics and finance». GPG Publishing Group, Pretoria, South Africa, Challenges and opportunities of scientific thought development: Collection of scientific articles, 2017, pp. 15-28, ISBN 978-0-9942661-6-3.

Terziev, V., Arabska, E. (2015). Opportunities of establishment of destination management and marketing organizations in Bulgaria. // International conference Enterprise and the Competitive Environment, March 5-6, 2015, Mendel University in Brno, 2015, ISBN 978-80-7509-342-4, pp.908-917.

Terziev, V., Banabakova, V., Ilsheva, M. (2018). Development of logistics in Bulgaria. // Knowledge International journal scientific papers, promoted in Vrnjacka Banja, Serbia 16-18.03.2018, Institute of Knowledge Management- Skopje, 22, 2018, N 2, pp. 503-510, ISSN 1857-923X, ISSN 2545-4439.

Terziev, V., Banabakova, V., Stefanov, S. (2017b). Development of a simulation model for accomplishing effective policy for logistic services. // Journal of International Business Studies, Palgrave Macmillan Ltd., 48, 2017, N 9 (2), pp.1389-1402, Source Normalized Impact per Paper (SNIP): 2.450, SCImago Journal Rank (SJR): 4.208, ISSN: 0047-2506 (print version), ISSN: 1478-6990 (electronic version).

Terziev, V., Banabakova, V., Ilsheva, M. (2017c). The cycle of the order as a base of logistics service of the clients. // Knowledge - International Journal September 2017, Institute of Knowledge Management, Skopje, 19, 2017, N 1, ISSN 1857-923X for e- version ISSN 2545-4439 for printed version, pp.133137. 
IJASOS- International E-Journal of Advances in Social Sciences, Vol. IV, Issue 12, December 2018

Terziev, V., Banabakova, V., Stefanov, S. (2017d). Simulation model for accomplishing effective policy for logistic services. // Proceedings of the 7 International Academic Congress "Science, Education and Culture in Eurasia and Africa" (France, Paris, 23-25 April 2017), Paris University Press, 72017, Source Normalized Impact per Paper (SNIP): 3.326 SCImago Journal Rank (SJR): 3.785 Impact factor: 3.9575-Yr impact factor: 4.205. ISBN: 978-2-547-47596-7, pp.289-301.

Terziev, V., Banabakova, V., Stefanov, S. (2017e). Development of a simulation model for accomplishing effective policy for logistic services. // Thirteenth International Scientific Conference The teacher of the future 25-28.5.2017, Budva, Montenegro, Institute of Knowledge Management, Skopje, 17, 2017, N1, ISSN 1857-923X for e- version ISSN 2545-4439 for printed version, pp.475-484.

Terziev, V., Banabakova, V., Stefanov, S., Georgiev, M. (2017f). Evolution of the marketing concept, marketing mix -,mix of components“ or a set of actions. // Fifteenth International Scientific Conference: Knowledge in practice, Bansko, Bulgaria, International Journal of Knowledge and Learning, Institute of Knowledge Management- Skopje, 20, 2017, N1, pp. 213-218, ISSN 1857-923X for e-version, ISSN 2545-4439 for printed version.

Terziev, V., Banabakova, V. (2017g). Marketing. // Annotirovannayy ukazately nauchnoy i uchebnometodicheskoy literaturay, predstavlennoy avtorami na I-XXXIII vserossiyskih vaystavkah, provodimayh akademiey estestvoznaniya http://rae.ru/ru/chronicle/, Materialay dlya ekspozitsii na XXX Moskovskoy Mezhdunarodnoy knizhnoy vaystavka-yarmarka Moskva, VDNH, pavilyon №75 06-10 sentyabrya 2017g. XXVIII, s.148 (Terziev, V., Banabakova, V. Marketing. // Аннотированный указатель научной и учебно-методической литературы, представленной авторами на I-XXXIII всероссийских выставках, проводимых академией естествознания http://rae.ru/ru/chronicle/, Материалы для экспозиции на XXX Московской Международной книжной выставка-ярмарка Москва, ВДНХ, павильон №75 06-10 сентября 2017г. XXVIII, с.148).

Terziev, V., Arabska, E. (2015a). Opportunities of establishment of destination management and marketing organizations in Bulgaria. // Journal of economic development, environment and people (JEDEP), 4, 2015, 2, ISSN 2285-3642, ISSN-L 2285-3642, pp.49-60.

Terziev, V., Banabakova, V. (2017h). Marketing, Institute of Management and Knowledge, Skopje, Macedonia, 2017, ISBN 978-608-4834-01-4, 197 p. 